\title{
THE IMPACT OF PERCEIVED ORGANIZATIONAL SUPPORT ON KNOWLEDGE SHARING: A MEDITATION ANALYSIS THROUGH AN SEM APPROACH
}

\author{
Alex Winarno \\ Telkom University, Indonesia \\ Arif Partono Prasetio \\ Telkom University, Indonesia \\ Nidya Dudija \\ Telkom University, Indonesia \\ Ciptaresmi Nadya Pratami \\ Telkom University Indonesia \\ Ran Liu \\ Central Connecticut State University, USA
}

\begin{abstract}
Mobile cellular providers need to continuously upgrade their human resources capability to cope with market demand. In a high technology organization, knowledge is crucial to beating the competition. To accelerate knowledge dissemination, organizations can optimize their employees to share their experience and knowledge with others. This study examines the role of organizational support and affective commitment in enhancing knowledge-sharing willingness. We used a questionnaire to collect data from cellular companies in Jakarta, Indonesia, receiving 237 useable responses. The study reveals that if employees perceive that the organization provides adequate support, they become more willing to share their knowledge with others. Adequate support also increases emotional commitment, which in the end proves valuable to drive the willingness to share. Thus, affective commitment plays a mediating role in the relationship between perceived organizational support and knowledge sharing. These findings provide new insight into how to enhance the spirit of sharing between employees.
\end{abstract}

Keywords: affective commitment, knowledge sharing, perceived organizational support.

DOI: http://dx.doi.org/10.15549/jeecar.v8i4.723 


\section{INTRODUCTION}

Knowledge is an essential resource for any organization, especially in profit-oriented companies. This is because knowledge can create a sustainable competitive advantage so that organizations can be ready to face future challenges (Demerouti et al., 2015). Therefore, knowledge management should become a priority in today's organizations. The collection of and learning new knowledge are the first steps in managing knowledge and then using learned knowledge to achieve business goals. Unfortunately, most organizations stop at this point; when their problems are solved, they tend to forget that they have essential knowledge which helps them succeed. Therefore, a variety of knowledge that has been acquired and utilized should be stored.

Furthermore, this critical knowledge needs to be disseminated to interested employees. Organizations gain benefits with knowledge dissemination or sharing, such as improving operations, developing positive collaboration and innovation, preventing potential loss of critical know-how, providing additional help with essential knowledge and solutions, and inspiring new solutions and development that drive changes (Malter, 2017). Meanwhile, Ahmad and Karim (2019) reviewed previous articles regarding knowledge sharing (K.S.) and found outcomes related to individuals, teams, and organizations. Factors affected by knowledge sharing can include creativity (Lee, 2018), job performance (Singh et al., 2017), organizational effectiveness and learning (Yang, 2010), and employees' job satisfaction (Trivellas et al., 2015).

The terms of knowledge sharing can be related to lessons that have been already learned, which are then made public and available to others. Curtis and Taylor (2018) described knowledge sharing (KS) as leveraging the skills, knowledge, and best practices of specific individuals to others inside the organization. Knowledge sharing comprises complex activities involving exchanging knowledge between individuals in the same organization and in multiple forms (Han et al., 2019). In short, KS is an activity that encompasses the distribution of knowledge and experiences owned by employees to others in the same organization, which complements the diversity of corporate knowledge. Sharing activity can be in the form of training, discussion, or any other learning means. KS can benefit individuals and organizations, yet employees are still reluctant to share their knowledge with others because the distribution of their essential knowledge can jeopardize their position in the organization. Thus, certain employees do not share their knowledge (Connelly \& Zweig, 2015). Organizations need to act promptly to prevent such an event, which can bring negative consequences. They have to identify factors that can reduce employee skepticism and drive a willingness to share knowledge.

This study examines the influences of organizational support and affective commitment towards employee's behavior in sharing knowledge. Previous studies in the area of KS had identified the relationship of several factors with KS behavior. For example, Anvari et al. (2014) found a positive effect of affective commitment (ACO) and compensation on KS. Castaneda and Duran (2018) identified a positive relationship between perceived organizational support (POS) and KS. Other factors that have been studied and found to have a relationship with KS include organizational citizenship behavior (Han et al., 2019), employee engagement (McKeown and Cochrane, 2012), organizational commitment (Muneer et al., 2014), human resource practice, and trust (Naeem et al., 2017). This study proposes the direct effect of POS on KS but also examines the indirect effect of ACO. Such a study is still limited, especially in a company that provides cellular services. To our best knowledge, the present study provides new insight and knowledge in the role of ACO as a variable that can mediate PCO and $\mathrm{KS}$, especially in the telecommunications industry. Whether ACO can help enhance the relationship between POS and KS or not. We studied data from employees in one Indonesian private cellular service using Structural Equation Modeling (SEM) to analyze the result. The organization of this article starts with an introduction to the importance of the study. Hypothesis development is based on previous literature examining the relationship between POS, ACO, and KS. The research methodology is then outlined, and the findings are presented and discussed. Finally, we provide conclusions, limitations, and suggestions for future research. 
Hopefully, this study can give a more significant contribution to optimizing the practice of knowledge sharing.

\section{LITERATURE REVIEW}

Knowledge Sharing, Perceived Organizational Support, and Affective Organizational Commitment

Wang \& Noe (2010) argued that POS is adequate management support often related to KS. According to Rhoades and Eisenberger (2002), POS is employees' belief that they had sufficient support from their organization regarding their jobs. Perception is an individual thought about something they believe to be, and this is very personal (Swift \& Virick, 2013). They can develop subjective perceptions about care and recognition from the organization. Thus, POS is a personal and subjective feeling of an employee towards the level of support they get from their organization. When discussing POS, is often linked with reciprocity norms (Gouldner, 1960). If one party perceived positive treatment from others, they would return the favor. Employees with a stronger perception regarding organization support (supportive work environment, great leadership, an adequate salary, promoting fairness in a career) tend to contribute and give more effort in their job. Stronger affective commitment, higher level of job satisfaction, developing stronger organizational citizenship behavior, increased in-role performance, job involvement, turnover intention, increase in organizational trust and identification, all lessen counter-productive behavior, promote knowledge sharing practice, reduce work stress, and also can provide a higher level of work-life balance (Pradesa et al., 2013; Arshadi, 2011; Rockstuhl et al., 2020; Chhetri, 2017; Han et al., 2019; Kang et al., 2010; Khalid \& Rathore, 2018). With so much at stake, organizations need to focus on how their programs, practices, and policies suit employees' needs and create a positive perception. Improve the relationship between the organization and employees is one function of POS.

As a part of the findings of organizational support theory (OST), perceived organizational support (POS) measures the extent to which an organization credits employees' contributions and is concerned with their wellbeing
(Eisenberger \& Stinglhamber, 2011). POS is highly related to the perceived fairness of HR practices and employees' attitudinal consequences, including job satisfaction and organizational commitment (Riggle, Edmonson, \& Hansen, 2009). POS is generated from employees' perceptions about the favorable treatment they receive from the organization. Based on the social exchange theory, the exchange partners need to maintain a balanced relationship that involves tangible/intangible benefits and social resources between the employee and the organization (Cropanzano \& Mitchell, 2005). The principle of reciprocity leads employees to make more tremendous efforts to improve job performance when they feel that their efforts will be noticed and rewarded. In other words, POS serves as an antecedent for employees to establish effective organizational commitment (Eisenberger et al., 2001). Socioemotional needs such as affiliation, esteem, and emotional support are fulfilled by POS, which is a cornerstone of effective organizational commitment and corporate values (Meyer, Becker, \& Van Dick, 2006). In accordance with OST, POS serves as an antecedent of a set of relationship outcomes (Shore et al., 2006). Kurtessis et al. (2015) argue that POS enhances social exchange while undercutting the economic exchange in relationships. Employees who have higher POS demonstrate a greater level of trust and are willing to take risks on behalf of the organization (Rousseau et al., 1998).

Having a close relation with the reciprocity concept, affective organizational commitment is also positive work attitude from employees towards their organization. Employee's ACO will be higher when they perceive that the organization has a great deal of conformity with what they expect. Mercurio (2015) argued that ACO is the essence of organizational commitment. Meanwhile, Meyer et al. (2012) considered ACO as an emotional attachment to, identification with, and involvement in the organization. ACO is a concept inside employees' minds that can affect how they act or behave. Management needs to understand essential factors that can help them infuse their employees to develop stronger ACO.

Some antecedents of ACO from previous studies include high-performance work practice, 
ethical leadership, job satisfaction, transformational leadership, learning culture, and perceived organizational support (Pattnaik \& Sahoo, 2019; Asif et al., 2019; Luturlean et al., 2019; Khan et al., 2019; Malik \& Garg, 2017; Albrecht \& Marty, 2017). Employees with stronger ACO will provide more benefits for organizations. Past studies from various cultural backgrounds found the contribution of ACO to decreasing absenteeism, boosting job satisfaction and can influence employees to stay longer, increase their job performance, promote organizational citizenship behavior, encourage knowledge-sharing, enhance organization trust from employees, and nurture helping behavior (Garland et al., 2013; Dinc et al., 2018; Kehoe \& Wright, 2013; Bandula \& Jayatilake, 2016; Lombardi et al., 2019; Wang et al., 2018; Naeem et al., 2017; Bagraim, 2010). Highly effective employees certainly will provide more contribution for organizations.

Best performance is an ultimate target for employees, and therefore exercising a topquality effort to finish their jobs will be beneficial for organizations. There are several ways to achieve such conditions. Moreover, one indirect way to contribute is to share knowledge with other employees who need it. Unfortunately, although it seems simple and easy, knowledge sharing practices are still rarely applied officially and sometimes still not considered as essential activities.

In comparison, knowledge sharing is one of the most fundamental activities in organizational operations (Ahmad \& Karim, 2019). Wang \& Noe (2010) described knowledge sharing as providing task-related information and knowhow to help other co-workers solve problems, develop new ideas, or implement policies or procedures. It can occur through oral or written communications directly and indirectly. Naim and Lengka (2017) conceptualized knowledge sharing as employees' participation in exchanging valuable knowledge, skills, and experiences with other members of the organization. In other words, knowledge sharing can be understood as the process of exchanging valuable task and job-related information between employees from various departments/divisions from the same organization whose goals are to help others learn in solving problems and create innovative ideas.

Knowledge sharing is considered essential because it can promote organizational effectiveness, innovative behavior, job satisfaction, organizational learning, and job performance (Yang, 2010; Mustika et al., 2020; Usmanova, 2020; Singh et al., 2017). Thus, this practice should be implemented across the entire organization, as it helps to spread proper knowledge and distribute valuable information to improve the way to do the job. Therefore, they must examine the most crucial aspect which can drive employees to share their knowledge. Lombardi et al. (2019) found a significant positive effect from ACO towards knowledge sharing behavior in museum workers in Italy. McKeown and Cochrane's (2012) study revealed the same positive effect from employee engagement on knowledge sharing using contractor employees in Australia. Other studies found human resource practices, organizational commitment, organizational trust, compensation, organizational citizenship behavior, and perceived organizational support as a construct that affects knowledge sharing behavior in Pakistan, Malaysia, and South Korea (Naeem et al., 2017; Muneer et al., 2014; Anvari et al., 2014; Han et al., 2019; Ali \& Dominic, 2017).

\section{Hypotheses Development}

POS will directly affect knowledge sharing practice, and ACO will play a mediating role in the relationship. When employees develop the positive perception that their organization values their contributions and treats them with respect (providing supportive work conditions, fair and just compensation, and excellent career opportunities), employees will reciprocate with a positive attitude and behavior like ACO and knowledge sharing behavior. These actions will help to achieve the organization's goals. Thus, previous research becomes references for determining the research hypothesis. Table 1 , Table 2, and Table 3 provide detailed findings regarding the relationship between POS, ACO, and knowledge sharing. 
Table 1: Relationship of pos and knowledge sharing

\begin{tabular}{|l|l|l|l|l|}
\hline \multicolumn{1}{|c|}{ Author(s) } & \multicolumn{1}{c|}{ Year } & \multicolumn{1}{c|}{ Country } & \multicolumn{1}{c|}{ Correlation } & \multicolumn{1}{c|}{ Industry } \\
\hline Indra & 2014 & Indonesia & Significant & Construction \\
\hline Jeung et al. & 2017 & South Korea & Significant & $\begin{array}{l}\text { Non-profit } \\
\text { organization }\end{array}$ \\
\hline Kusumowardhani & 2011 & Indonesia & Significant & Healthcare \\
\hline McKeown \& Cochrane & 2012 & Australia & Significant & Contractor \\
\hline
\end{tabular}

Table 2: Relationship of ACO and knowledge sharing

\begin{tabular}{|l|l|l|l|l|}
\hline \multicolumn{1}{|c|}{ Author(s) } & \multicolumn{1}{c|}{ Year } & \multicolumn{1}{c|}{ Country } & Correlation & \multicolumn{1}{c|}{ Industry } \\
\hline Dey \& Mukhopad & 2018 & India & Significant & Various \\
\hline Ficapal-Cusi et al. & 2020 & Spain & Significant & Various \\
\hline Hwang \& Kim & 2007 & United States & Significant & Various \\
\hline Jeung et al. & 2017 & South Korea & Significant & $\begin{array}{l}\text { Non-profit } \\
\text { organization }\end{array}$ \\
\hline
\end{tabular}

Table 3: Relationship of POS and ACO

\begin{tabular}{|l|l|l|l|l|}
\hline \multicolumn{1}{|c|}{ Author(s) } & \multicolumn{1}{c|}{ Year } & \multicolumn{1}{c|}{ Country } & \multicolumn{1}{c|}{ Correlation } & \multicolumn{1}{c|}{ Industry } \\
\hline Donald et al. & 2016 & South Korea & Significant & Academic \\
\hline Stinglhamber et al. & 2015 & Belgium & Significant & Public organization \\
\hline Harthantyo \& Rahardjo & 2017 & Indonesia & Significant & Hospital \\
\hline Jeung et al. & 2017 & Korea & Significant & $\begin{array}{l}\text { Non-profit } \\
\text { organization }\end{array}$ \\
\hline
\end{tabular}

Since we also examine the role of ACO as a mediator, we therefore seek previous studies which proved the mediating role of ACO (Table
4). As a result, ACO proved to have a significant role in linking the relationship of the independent and dependent constructs.

Table 4: Relationship of ACO as a mediator

\begin{tabular}{|l|l|l|l|l|l|l|}
\hline \multicolumn{1}{|c|}{ Author(s) } & Year & Country & Correlation & \multicolumn{1}{|c|}{ Industry } & $\begin{array}{l}\text { Antecedent } \\
\text { Variable }\end{array}$ & $\begin{array}{c}\text { Outcome } \\
\text { Variable }\end{array}$ \\
\hline Naeem et al. & 2017 & Pakistan & Significant & Education & H.R. practice & KS \\
\hline Gupta et al. & 2016 & India & Significant & Hospital & POS & OCB \\
\hline Jeung et al. & 2017 & $\begin{array}{l}\text { South } \\
\text { Korea }\end{array}$ & Significant & Education & POS & KS \\
\hline Karatepe & 2015 & Romania & Significant & Hotel & POS & Performance \\
\hline
\end{tabular}

Based on the previous findings, we propose the following hypotheses:

H1: POS is positively associated with K.S.

H2: The effect of POS on K.S. will be mediated by the level of ACO.

\section{METHODOLOGY}

Participants and Procedures
A cross-sectional survey design is used to gather primary data, which were collected using a questionnaire. The sample is from a private cellular company based in Jakarta. We contacted one of the management representatives who helped to distribute the questionnaire to their employees. We provided 375 sets of questionnaires and used a non-probability method to get 250 responses, of which only 237 were usable (63.2\%). We provided no reward; 
thus, participation in the study was voluntary. Participants were asked to choose one answer from a six-point Likert scale: strongly disagree (1) and strongly agree (6). Male participants represented $59.9 \%$ of the sample; most were at an officer level (65\%). Employees between the ages of 25-30 years dominated the participants in this study (28.7\%). Interestingly, $37.1 \%$ of the participants have worked for more than five years in the organization. We ensured the confidentiality of the participants involved.

\section{Observed Variables}

There were 17 observed variables (indicator) which were divided as follows; 6 observed variables (indicator) for POS, five observed variables (indicator) for $\mathrm{KS}$, and six observed variables (indicators) for ACO. The development of a questionnaire for POS refers to the work from Eisenberger et al., (2001). The sample indicator is
"Organization cares about my wellbeing." Meanwhile, an indicator of ACO taken from Azis et al. (2019) and the sample is "I oftenly talk positive things about the organization with others." Finally, five indicators for K.S. develop from Teh \& Sun (2012), and the sample is "After acquiring new knowledge, I immediately passed it on to my colleagues."

\section{DISCUSSION AND FINDING}

\section{The goodness of Fit Model}

The goodness of fit indicates the comparison between the specified model and the covariance matrix indicators or observed variables. If the goodness of fit of a model is good, then the model is accepted, and if the goodness of fit of a model is bad, the model must be rejected or modified. Table 2 shows the overall model fit analysis result.

Table 5: Overall Model Fit Analysis

\begin{tabular}{|c|c|c|c|c|}
\hline $\begin{array}{l}\text { The goodness of } \\
\text { Fit Parameters }\end{array}$ & $\begin{array}{c}\text { First } \\
\text { Estimated } \\
\text { Parameters }\end{array}$ & $\begin{array}{c}\text { Second } \\
\text { Estimated } \\
\text { Parameters }\end{array}$ & Cut-off Value & $\begin{array}{c}\text { Testing } \\
\text { Conclusion }\end{array}$ \\
\hline \multicolumn{5}{|l|}{ Absolute Fit } \\
\hline CMIN/DF & 2.79 & 1.42 & $<2.00$ & Good Fit \\
\hline P-Value & 0.000 & 0.002 & $\geq 0.05$ & Poor Fit \\
\hline RMSEA & 0.09 & 0.04 & $\leq 0.08$ & Good Fit \\
\hline GFI & 0.85 & 0.93 & $>0.90$ & Good Fit \\
\hline RMR & 0.70 & 0.05 & $<0.08$ & Good Fit \\
\hline ECVI & 1.89 & 1.03 & $<$ Saturated model $=1.29$ & Good Fit \\
\hline \multicolumn{5}{|l|}{ Incremental Fit } \\
\hline CFI & 0.90 & 0.98 & $>0.90 ;>0.95$ & Good Fit \\
\hline NFI & 0.85 & 0.94 & $>0.90 ;>0.95$ & Good Fit \\
\hline TLI & 0.88 & 0.97 & $>0.90 ;>0.95$ & Good Fit \\
\hline IFI & 0.90 & 0.98 & $>0.90 ;>0.95$ & Good Fit \\
\hline RFI & 0.83 & 0.92 & $>0.90 ;>0.95$ & Marginal Fit \\
\hline AGFI & 0.81 & 0.90 & $\geq 0.90$ & Good Fit \\
\hline \multicolumn{5}{|l|}{ Parsimonious Fit } \\
\hline PGFI & 0.66 & 0.66 & $>0.60$ & Good Fit \\
\hline AIC & 446.113 & 244.12 & $<$ Saturated model $=306.00$ & Good Fit \\
\hline CAIC & 620.368 & 445.18 & $<$ Saturated model = 989.61 & Good Fit \\
\hline
\end{tabular}


Based on Table 5, there are 13 Good Fits, 1 Marginal Fit, and 1 Poor Fit, which means we can conclude that there is a good fit between the data and mode. The RMSEA also is better now, at 0.04; a good fit. We can continue to the next test, namely Measurement Model Fit Analysis.

The measurement model fit analysis for validity testing can be done by conducting: (1) A Construct Validity Test, (2) a Convergent Validity Test, and (3) a Reliability Test. In this step, we will do the Construct Validity Test first by looking at the "CR (Critical Ratio)" score then the "P (Probability)." If the CR is > 1.96 (1.96 is the critical value at the significant level 0.05 ) and $\mathrm{P}<$ 0.05 . then the indicator is VALID, able to reflect the latent variable. If the "P" score show "***," it means that the "P" score is significant, targeted < 0.001 .

Table 7: Regression Weights

\begin{tabular}{|c|c|c|c|c|c|c|}
\hline & & Estimate & S.E. & C.R. & $P$ & Label \\
\hline ACO & $<---\quad$ POS & .4422 & .0700 & 6.3202 & $* * *$ & par_1 \\
\hline K.S. & $<---\quad$ ACO & .3179 & .0807 & 3.9406 & $* * *$ & par_2 \\
\hline K.S. & $<---\quad$ POS & .2849 & .0626 & 4.5485 & $* * *$ & par_3 \\
\hline POS6 & $<---\quad$ POS & 1.0000 & & & & \\
\hline POS5 & $<---\quad$ POS & 1.1799 & .0875 & 13.4784 & $* * *$ & par_4 \\
\hline POS4 & <--- $\quad$ POS & 1.1700 & .0796 & 14.6995 & $* * *$ & par_5 \\
\hline POS3 & $<---\quad$ POS & 1.2741 & .0853 & 14.9397 & $* * *$ & par_6 \\
\hline POS2 & <--- $\quad$ POS & 1.1319 & .0923 & 12.2679 & $* * *$ & par_7 \\
\hline POS1 & $<---\quad$ POS & .9653 & .0905 & 10.6615 & $* * *$ & par_8 \\
\hline KS1 & $<---\quad K S$ & 1.0000 & & & & \\
\hline KS2 & $<---\quad K S$ & 1.1258 & .0619 & 18.1953 & $* * *$ & par_9 \\
\hline KS3 & <--- $\quad \mathrm{KS}$ & 1.0037 & .0832 & 12.0634 & $* * *$ & par_10 \\
\hline KS4 & $<---\quad K S$ & .8461 & .0671 & 12.6163 & $* * *$ & par_11 \\
\hline KS5 & $<---\quad K S$ & .8352 & .0717 & 11.6537 & $* * *$ & par_12 \\
\hline ACO1 & $<---\quad$ ACO & 1.0000 & & & & \\
\hline $\mathrm{ACO} 2$ & $<---\quad$ ACO & .9264 & .1047 & 8.8502 & $* * *$ & par_13 \\
\hline ACO3 & $<---\quad$ ACO & 1.0163 & .1243 & 8.1748 & $* * *$ & par_14 \\
\hline ACO4 & $<---\quad$ ACO & .7841 & .1121 & 6.9960 & $* * *$ & par_15 \\
\hline ACO5 & $<---\quad$ ACO & 1.0699 & .1066 & 10.0354 & $* * *$ & par_16 \\
\hline ACO6 & $<---\quad$ ACO & .9348 & .1114 & 8.3898 & $* * *$ & par_17 \\
\hline
\end{tabular}

Based on Table 7, we can see from the Amos output that all observed variables have a CR score $>1,96$, and the P score shows '***,' which means $<0,05$. Therefore, we conclude that the result of the measurement model fit analysis is fit for the construct validity test. We can then continue the next step with the Convergent Validity Test to test whether there is a high variance proportion or not. All the items/observed variables/ indicators of a latent variable should be converging or share a high variance proportion. The Convergent Validity Test can be concluded by looking at the "Loading Factor" or the "Standardized Loading Factor/SLF" score. If the SLF score is high, it shows that the observed variable and its latent variables are converged or 
valid. The convergent validity holds if the SLF score is $\geq 0.70$ (Hair et al., 2019).

All observed variables have a "Standardized Loading Factor/SLF" $\geq 0.70$, leading to the conclusion that all the variables are valid. Two observed variables, namely ACO4 and ACO3, however, have an SLF score $\leq 0.70$. Based on Hair et al. (2005), those two observed variables are still valid (if the SLF score is $\geq 0.05$, it means valid). The summary of all the validity testing is shown in Table 8 below.

Table 8: Summary of All Validity Testing Results

\begin{tabular}{|l|l|l|l|l|l|l|l|l|l|l|}
\hline \multirow{2}{*}{$\begin{array}{l}\text { Observed } \\
\text { Variables }\end{array}$} & \multicolumn{3}{|c|}{$\begin{array}{c}\text { Perceived } \\
\text { Organizational Support } \\
\text { (POS) }\end{array}$} & \multicolumn{3}{c|}{$\begin{array}{c}\text { Affective Commitment } \\
\text { (ACO) }\end{array}$} & \multicolumn{2}{c|}{$\begin{array}{c}\text { Knowledge Sharing } \\
\text { (KS) }\end{array}$} & $\begin{array}{c}\text { Validity } \\
\text { Conclusi } \\
\text { on }\end{array}$ \\
\cline { 2 - 12 } & C.R. & P & SLF & CR & P & SLF & CR & P & SLF & \\
\hline POS1 & 10.661 & 0.000 & .678 & & & & & & & Valid \\
\hline POS2 & 12.268 & 0.000 & .735 & & & & & & & Valid \\
\hline POS3 & 14.939 & 0.000 & .917 & & & & & & & Valid \\
\hline POS4 & 14.699 & 0.000 & .853 & & & & & & & Valid \\
\hline POS5 & 13.478 & 0.000 & .856 & & & & & & & Valid \\
\hline POS6 & $*$ & 0.000 & .763 & & & & & & & Valid \\
\hline ACO1 & & & & $*$ & 0.000 & .650 & & & & Valid \\
\hline ACO2 & & & & 8.850 & 0.000 & .704 & & & & Valid \\
\hline ACO3 & & & & 8.175 & 0.000 & .626 & & & & Valid \\
\hline ACO4 & & & & 6.996 & 0.000 & .536 & & & & Valid \\
\hline ACO5 & & & & 10.035 & 0.000 & .825 & & & & Valid \\
\hline ACO6 & & & & 8.389 & 0.000 & .676 & & & & Valid \\
\hline KS1 & & & & & & & $*$ & 0.000 & .866 & Valid \\
\hline KS2 & & & & & & & 18.195 & 0.000 & .905 & Valid \\
\hline KS3 & & & & & & & 12.063 & 0.000 & .691 & Valid \\
\hline KS4 & & & & & & & 12.616 & 0.000 & .717 & Valid \\
\hline KS5 & & & & & & & 11.654 & 0.000 & .710 & Valid \\
\hline
\end{tabular}

Reliability Testing with Construct Reliability (CR): The test is measuring how reliable and consistent the data is. The $\mathrm{CR}$ score can be calculated using the formula below:

$$
\text { Construct Reliability }(\mathrm{CR})=\frac{\left(\sum \text { std.loading }\right)^{2}}{\left(\sum \text { std.loading }\right)^{2}+\sum e j}
$$

The CR score $\geq 0.70$ shows good reliability in the latent variable/construct (Hair et al.,2019). However, the $0.60 \geq \mathrm{CR} \leq 0.70$ is still acceptable if the validity testing results for the indicator are valid. Therefore, with the above formula, we can count the CR score for the latent variables.

Another reliability test is the Average Variance Extracted (AVE/VE) to complete the CR score. The AVE score can be counted using this below formula:

$$
\text { Variance Estracted (VE) }=\frac{\sum \text { std.loading }{ }^{2}}{\sum \text { std.loading }{ }^{2}+\sum e j}
$$

The AVE score $\geq 0.50$ means there is excellent convergence in the latent variable/construct. CR and VE score, as shown in Table 9. 
Table 9: Summary Of All Reliability Testing Results

\begin{tabular}{|l|l|l|l|}
\hline Latent Variables & C.R. Score & VE Score & Reliability Conclusion \\
\hline Perceived Organizational Support (POS) & $0.93 \geq 0.70$ & $0.65 \geq 0.50$ & Reliable \\
\hline Affective Commitment (ACO) & $0.85 \geq 0.70$ & $0.50 \geq 0.50$ & Reliable \\
\hline Knowledge Sharing (KS) & $0.88 \geq 0.70$ & $0.51 \geq 0.50$ & Reliable \\
\hline
\end{tabular}

\section{FINDINGS}

Based on Table 9, we can conclude that all the latent variables are Reliable. As all the variables passed the reliability testing, we can continue to the subsequent testing fit analysis, namely the Structural Model Fit Analysis or Hypothesis Analysis. The critical decision in Structural Model
Fit or Hypothesis Testing is checking the P-Value with the significant level (alpha) at 0.05 or comparing the CR (Critical Ratio) score with the t-table (1.96) (Sekaran \& Bougie, 2016). Table 10, shows the result for the Testing Fit - Structural Model Fit Analysis (Hypothesis Testing).

Table 10: Hypothesis Testing

\begin{tabular}{|l|l|l|l|l|l|}
\hline Hypothesis & Path & $\begin{array}{l}\text { Standardized } \\
\text { Loading }\end{array}$ & P-Value & $\begin{array}{l}\text { C.R. } \\
\text { Score }\end{array}$ & $\begin{array}{l}\text { Hypothesis } \\
\text { Conclusion }\end{array}$ \\
\hline 1 & POS ---> ACO & .512 & 0.000 & 6.320 & Significant \\
\hline 2 & ACO ---> KS & .319 & 0.000 & 3.940 & Significant \\
\hline 3 & POS ---> KS & .331 & 0.000 & 4.549 & Significant \\
\hline
\end{tabular}

Based on the above results, all relationships have a CR (Critical Ratio) score > 1.96, P-value all have < 0.05 as well, and evaluating the standardized loading factor, all have $<1.00$. Therefore, we conclude that all the hypotheses are accepted.

Table 10 shows the correlations between variables, which confirm that POS and ACO have a positive relation with $\mathrm{KS}$, and ACO positively relates with $\mathrm{KS}$. Hence, our findings support the previous results from Donald et al. (2016), Jeung et al. (2017), and (Dey \& Mukhopadhyay, 2018). It can be said that various discussions regarding those variables from a collective cultural background in Indonesia bring the same result with previous studies (both individual and collective backgrounds).

Our results show that hypotheses $\mathrm{H} 1, \mathrm{H} 2$, and H3 are supported; POS significantly affects KS, p $<0.05$. Studies from Malaysia and Colombia support this finding (Ali \& Dominic, 2017; Castaneda \& Duran, 2018). Positive perception regarding an organization's support can lead to the increase of intention to share valuable knowledge. POS also proved to be a significant factor that affects ACO ( $p<0.05)$. This corresponds to the result from South Africa and Belgium (Donald et al., 2016; Stinglhamber et al., 2015). Employees who perceived good support will develop emotional attachment towards the organization. With this emotional attachment, employees will give their best to help the organization survive. This study reveals that ACO affects knowledge sharing $(\mathrm{P}<0.05)$. Previous studies that had the same findings were Jeung et al. (2017) in South Korea, Lombardi et al. (2019) in Italy, and Naeem et al. (2017) in Pakistan.

This study contributes to the literature on knowledge management, especially in private technology-based organizations. Yang (2010), Mustika et al. (2020), and Usmanova (2020) believed that the practice of knowledge sharing would have a significant impact on the organization's effectiveness and innovative behavior. The result. This study confirms the combined effects of POS and ACO on KS. Management should focus on improving their support for employees. They need to identify what kind of support is needed. By doing so, the organization also shows their care for employees. Important factors that can be focused on are the provision of adequate work tools, 
freedom, and independence in carrying out work, less control and giving more responsibility, and open and direct communication with management to share ideas and give solutions. Such an approach will shape employees' positive mindset and gradually build close relations. If this condition runs continuously, it can create emotional attachment or affective commitment from employees. Then the organization can reap many benefits to help it grow. Knowledgesharing behavior is linked with positive feelings and trust in the mind of employees. Receiving great treatment and possessing close relations will encourage them to participate in the distribution of old and new knowledge to others. Employees do not need to be told to share, and they will actively promote knowledge sharing to whoever needed it. This also reduces reluctance to share because of doubt that there will be a loss for employees who share since a strong bond has formed between management and employees. Extensive knowledge sharing also facilitates individual and group learning inside the organization that can lead to more innovative behavior and job performance. Besides, a sense of trust and cooperation between employees is also easily formed.

\section{Theoretical Implications}

The value of our study lies in the examination of the relationship between POS, OCB, and KS in a specific organizational context (private cellular company). The results suggest that organizational support theory from Eisenberger et al. (1986) and social exchange interact with each other to support our framework in promoting intense knowledge-sharing practices. We also confirm the result of similar studies from Ficapal-Cusi et al. (2020) and Camelo-Ordaz et al. (2011) in Spain. This mean ACO still has the mediating role in different cultural background and in various organizations. Thus, such a framework can be applied in a different situation.

In the context of Indonesia (especially the telecommunications industry), the results of this study emphasize that in the role of POS and ACO in supporting $\mathrm{KS}$, the level of intensity is influenced by the national culture that shapes corporate culture. In this context, the diverse national culture of Indonesia's also gives color to the implementation of corporate culture.

\section{Practical Implications}

The highlight of this study is in the urgency to create the conditions in organizations that enhance employees' perceptions and the development of an emotional relationship. We found the indirect effects of ACO, which mediate the relation of POS and KS. POS leads to higher $\mathrm{ACO}$, and then the latter helps increase the spirit of sharing. Cellular service needs continuous improvement and innovation. Organizations can organize training, invite cellular technology experts, send employees to an international exhibition, and send them to a supplier to learn future practices in cellular. They need to cope with the growing demands from customers and the government as regulators. Learning new things is essential, yet organizations have only limited resources. Learning is one thing, the dissemination to all levels is another. To accelerate the dissemination of the various knowledge that has been acquired, organizations rely on their employees. It is important to know that organizational support is more likely to drive employees' positive behavior toward others than concurrently helping them in sharing activities. Such findings mean that H.R. should provide desirable programs and policies which can facilitate employee involvement in knowledge sharing practice. For example, they can provide bonuses or incentives for those who actively share knowledge. The HR department needs to conduct a re-design of work that promotes self-efficacy and independence carefully.

\section{REFERENCES}

Ahmad, F., \& Karim, M. (2019). Impacts of knowledge sharing: a review and directions for future research. Journal of Workplace Learning, 31, 207-230. https://doi.org/10.1108/JWL-07-2018-0096

Albrecht, S. L., \& Marty, A. (2017). Personality, self-efficacy, and job resources and their associations with employee engagement, affective commitment, and turnover intentions. The International Journal of Human Resource Management, 1-25. https://doi.org/10.1080/09585192.2017.136 2660. 
Ali, A. A., \& Dominic, P. D. D. (2017). The relationship between management support and individual motivation for knowledge sharing practice. International Conference on Research and Innovation in Information Systems (ICRIIS). https://doi.org/10.1109/icriis.2017.8002441.

Anvari, R., Mansor, N. N. A., Rahman, S. A. B. P. A., Rahman, R. H. B. A., \& Chermahini, S. H. (2014). Mediating Effects of Affective Organizational Commitment and Psychological Contract in the Relationship between Strategic Compensation Practices and Knowledge Sharing. Procedia - Social and Behavioral Sciences, 129, 111-118. https://doi.org/10.1016/j.sbspro.2014.03.65 5.

Arshadi, N. (2011). The Relationships of Perceived Organizational Support (POS) With Organizational Commitment, In-Role Performance, and Turnover Intention Mediating Role of Felt Obligation. Social and Behavioral Sciences, 30, 1103-1108.

Asif, M., Qing, M., Hwang, J.S., \& Shi, H. (2019). Ethical Leadership, Affective Commitment, Work Engagement, and Creativity: Testing a Multiple Mediation Approach.

Sustainability, 11(16), 4489. https://doi.org/10.3390/su11164489.

Azis E., Prasetio A.P., Gustyana T.T., Putril S.F., \& Rakhmawati D. (2019). The Mediation of Intrinsic Motivation and Affective Commitment in the Relationship of Transformational Leadership \& Employee Engagement in Technology-Based Companies. Polish Journal of Management Studies, 20(1), 54 - 63. https://doi.org/ 10.17512/pjms.2019.20.1.05.

Bagraim, J. (2010). Multiple Affective Commitments and Salient Outcomes: The Improbable Case of Information Technology Knowledge Workers. The Electronic Journal Information Systems Evaluation, 13(2), 97106.

http://www.ejise.com/issue/download.html ?idArticle $=668$.

Bandula, P., \& Jayatilake, L. V. (2016). Impact of Employee on Job Performance: Based on Leasing Companies in Sri Lanka.
International Journal of Arts and Commerce, 5(8), 8-22.

Camelo-Ordaz, C., García-Cruz, J., Sousa-Ginel, E., \& Valle-Cabrera, R. (2011). The influence of human resource management on knowledge sharing and innovation in Spain: the mediating role of affective commitment. The International Journal of Human Resource Management, 22(7), 1442-1463. https://doi.org/10.1080/09585192.2011.561 960.

Castaneda, D.I., \& Durán, W.F. (2018). Knowledge sharing in organizations: Roles of beliefs, training, and perceived organizational support. Knowledge Management \& E-Learning, 10(2), 148-162. http://www.kmeljournal.org/ojs/index.php/onlinepublication/article/view/19.

Chhetri, S.B. (2017). Predictors and Outcomes of Employee Engagement: Empirical Study of Nepali Employees. Journal of Business and Management Research, 2(1 \& 2), 14-32. https://doi.org/10.3126/jbmr.v2i1-2.18149.

Connelly, C. E., \& Zweig, D. (2015). How perpetrators and targets construe knowledge hiding in organizations. European Journal of Work and Organizational Psychology, 24(3), 479-489.

Cropanzano, R., \& Mitchell, M. S. 2005. Social exchange theory: An interdisciplinary review. Journal of Management, 31: 874900.

Curtis, M. B., \& Taylor, E. Z. (2018). Developmental mentoring, affective organizational commitment, and knowledge sharing in public accounting firms. Journal of Knowledge Management, 22(1), 142-161. https://doi.org/10.1108/jkm-03-2017-0097.

Demerouti, E., Bakker, A. B., \& Gevers, J. M. P. (2015). Job crafting and extra-role behavior: The role of work engagement and flourishing. Journal of Vocational Behavior, 91(1), 87-96.

Dey, T., \& Mukhopadhyay, S. (2018). Influence of Behavioral Intentions, Affective Trust and Affective Commitment on Knowledge Sharing Behavior. International Journal of Knowledge Management, 14(2), 37-51. https://doi.org/10.4018/ijkm.2018040103. 
Dinc, M. S., Kuzey, C., \& Steta, N. (2018). Nurses' Job Satisfication as A Mediator of The Relationship between Organizational Commitment Components and Job Performance. Journal of Workplace Behavioral Health, 33(2), 75-95. https://doi.org/10.1080/15555240.2018.146 4930.

Donald, M.F., Hlanganipai, N., \& Richard, S. (2016). The Relationship between Perceived Organizational Support and Organizational Commitment among Academics: The Mediating Effect of Job Satisfaction. Investment Management and Financial Innovations, 13(3), 267-273.

Eisenberger, R., Armeli, S., Rexwinkel, B., Lynch, P.D., \& Rhoades, L. (2001). Reciprocation of perceived organizational support. Journal of Applied Psychology, 86, 42-51. https://doi.org/10.1037/0021-9010.86.1.42.

Eisenberger, R., Huntington, R., Hutchison, A., \& Sowa, D. (1986). Perceived Organizational Support. Journal of Applied Psychology, 71(3), 500-507. https://doi.org/10.1037/0021-9010.71.3.500.

Eisenberger, R., \& Stinglhamber, F. 2011. Perceived organizational support: Fostering enthusiastic and productive employees. Washington, DC: American Psychological Association.

Ficapal-Cusí, P., Enache-Zegheru, M., \& TorrentSellens, J. (2020). Linking Perceived Organizational Support, Affective Commitment, and Knowledge Sharing with Prosocial Organizational Behavior of Altruism and Civic Virtue. Sustainability, 12(24), 10289. https://doi.org/10.3390/su122410289.

Garland, B., Hogan, N.L., Kelley, T., Kim, K., \& Lambert, E.G. (2013). To Be or Not to Be Committed: The Effects of Continuance and Affective Commitment on Absenteeism and Turnover Intent among Private Prison Personnel. Journal of Applied Security Research, 8(1), 1-23. https://doi.org/10.1080/19361610.2013.738 402.

Gouldner, A.W. (1960). The Norm of Reciprocity: A Preliminary Statement. American
Sociological Review, 25(2), 161-178. https://doi.org/10.2307/2092623.

Gupta, V., Agarwal, U. A., \& Khatri, N. (2016). The relationships between perceived organizational support, affective commitment, psychological contract breach, organizational citizenship behavior and work engagement. Journal of Advanced Nursing, 72(11), 2806-2817. https://doi.org/10.1111/jan.13043.

Hair, J. F., Risher, J. J., Sarstedt, M., \& Ringle, C. M. (2019). When to use and how to report the results of PLS-SEM. European Business Review, 31(1), 2-24. https://doi.org/10.1108/EBR-11-2018-0203

Hair, J.F., W.C. Black, B.J. Babin, R.F. Anderson \& R.L. Tatham. 2005. Multivariate Data Analysis, 6th Edition. New Jersey: Prentice hall, Inc.

Han, S.-H., Yoon, D.-Y., Suh, B., Li, B., \& Chae, C. (2019). Organizational support on knowledge sharing: a moderated mediation model of job characteristics and organizational citizenship behavior. Journal of Knowledge Management, 23(4), 687-704. https://doi.org/10.1108/JKM-03-2018-0213

Harthantyo, Y. \& Rahardjo, M. (2017). Pengaruh Leader-Member Exchange (LMX) dan Perceived Organizational Support (POS) terhadap Komitmen Afektif (Studi Kasus Pada Karyawan Rumah Sakit Mekar Sari Bekasi). Diponegoro Journal of Management, 6(4), 1-13.

Hayes, A.F. (2018). Introduction to Mediation, Moderation, and Conditional Process Analysis: A Regression-Based Approach, 2nd Edition. New York: The Gilford Press.

Hwang, Y. \& Kim, D. J. (2007). Understanding Affective Commitment, Collectivist Culture, and Social Influence in Relation to Knowledge Sharing in Technology Mediated Learning. IEEE Transactions on Professional Communication, 50(3), 232-248. https://doi.org/10.1109/tpc.2007.902664.

Indra, M.I.S. (2014). Pengaruh Dukungan Organisasi Terhadap Perilaku Berbagi Pengetahuan Dimediasi Oleh Kepercayaan Organisasi dan Komitmen Organisasi. Jurnal Ilmu Manajemen, 2(2), 586-599. 
Jeung, C.W., Yoon, H.J., \& Choi, M.W. (2017). Exploring the affective mechanism linking perceived organizational support and knowledge sharing intention: a moderated mediation model. Journal of Knowledge Management, 21(4), 946-960. https://doi.org/10.1108/JKM-12-2016-0530.

Kang, B., Twigg, N. W., \& Hertzman, J. (2010). An examination of social support and social identity factors and their relationship to certified chefs' burnout. International Journal of Hospitality Management, 29(1), 168-176. https://doi.org/10.1016/j.ijhm.2009.08.004.

Karatepe, O. M. (2015). High-Performance Work Practices, Perceived Organizational Support, and Their Effects on Job Outcomes: Test of a Mediational Model. International Journal of Hospitality \& Tourism Administration, 16(3), 203-223.

https://doi.org/10.1080/15256480.2015.105 4753.

Kehoe, R.R., \& Wright, P.M. (2013). The Impact of High-Performance Human Resource Practices on Employees' Attitudes and Behaviors. Journal of Management, 39(2), 366-391. https://doi.org/10.1177/0149206310365901

Khalid, A. \& Rathore, K. (2018). Mediating Effect of Work-Life Balance on Work Motivation of Post Graduate Trainee Doctors in Public Sector Hospitals: Evidence from Pakistan. Pakistan Economic and Social Review, 56(1), 93-119.

https://doi.org/10.13140/RG.2.2.17478.6304 6.

Khan, A. N., Ali, A., Khan, N. A., \& Jehan, N. (2019). A study of relationship between transformational leadership and task performance: the role of social media and affective organizational commitment. International Journal of Business Information Systems, 31(4), 499. https://doi.org/10.1504/ijbis.2019.101583.

Kurtessis, J. N., Eisenberger, R., Ford, M. T., Buffardi, L. C., Stewart, K. A., \& Adis, C. S. (2017). Perceived organizational support: A meta-analytic evaluation of organizational support theory. Journal of Management, 43(6), 1854-1884.

Kusumowardhani, R. P. (2011). Perilaku Berbagi Pengetahuan dalam Organisasi Ditinjau dari Persepsi Tentang Dukungan Organisasi. Jurnal SPIRITS, 1(2), 97-224.

Lee, J. (2018). The Effects of Knowledge Sharing on Individual Creativity in Higher Education Institutions: Socio-Technical View. Administrative Sciences, 8, 21. https://doi.org/10.3390/admsci8020021

Lombardi, S., Sassetti, S., \& Cavaliere, V. (2019). Linking employees' affective commitment and knowledge sharing for an increased customer orientation. International Journal of Contemporary Hospitality Management, 31(11), 4293-4312. https://doi.org/10.1108/ijchm-03-20180261.

Luturlean, B. S., Prasetio, A.P, \& Saragih, R. (2019). Increasing Employee's Job Satisfaction Through the Implementation of Transformational Leadership and Work Stress Level Management. Journal of Management \& Marketing Review, 4(3) 209-217. https://doi.org/10.35609/jmmr.2019.4.3(6).

Malik, P., \& Garg, P. (2017). The relationship between learning culture, inquiry and dialogue, knowledge sharing structure and affective commitment to change. Journal of Organizational Change Management, 30. https://doi.org/10.1108/JOCM-09-20160176

Malter, A. (2017). The Importance of Knowledge Sharing. https://www.paisboa.org/index.php?option =com_dailyplanetblog\&view=entry\&categor $\mathrm{y}=$ notes-from-the-executivedirector\&id=34:the-importance-ofknowledge-sharing. Accessed April 21, 2021.

McKeown, T. \& Cochrane, R. (2012). Professional Contractor Wellbeing: Mutual Benefits of Organisational Support. International Journal of Manpower, 33(7), 786-803. https://doi.org/10.1108/0143772121126832 0 .

Mercurio, Z.A. (2015). Integrative Literature Review Affective Commitment as a Core Essence of Organizational Commitment: An 
Integrative Literature Review. Human Resource Development Review, 14(4), 389414. https://doi.org/10.1177/1534484315603612

Meyer, J. P., Becker, T. E., \& Van Dick, R. 2006. Social identities and commitments at work: Toward an integrative model. Journal of Organizational Behavior, 27: 665-683.

Meyer, J. P., Stanley, D. J., Jackson, T. A., McInnis, K. J., Maltin, E. R., \& Sheppard, L. (2012). Affective, normative, and continuance commitment levels across cultures: A metaanalysis. Journal of Vocational Behavior, $80(2), 225-245$. https://doi.org/10.1016/j.jvb.2011.09.005.

Muneer, S., Iqbal, S. M. J., Khan, S. R., Long, C. S. (2014). An Incorporated Structure of Perceived Organizational Support, Knowledge-Sharing Behavior, Organizational Trust and Organizational Commitment: A Strategic Knowledge Management Approach. Pakistan Journal of Commerce and Social Science, 8(1), 42-57.

Mustika, A.I., Rahardjo, K., \& Prasetya, A. (2020). The Effect of Perceived Organizational Support on Knowledge Sharing and Innovative Work Behavior. Advances in Economics, Business and Management Research, 154. Proceedings of the 2nd Annual International Conference on Business and Public Administration (AICoBPA 2019).

Naeem, A., Mirza, N. H., Ayyub, R. M., \& Lodhi, R. N. (2017). HRM practices and faculty's knowledge sharing behavior: mediation of affective commitment and affect-based trust. Studies in Higher Education, 1-14. https://doi.org/10.1080/03075079.2017.137 8635.

Naim, M. F., \& Lenka, U. (2017). Linking knowledge sharing, competency development, and affective commitment: evidence from Indian Gen Y employees. Journal of Knowledge Management, 21(4), 885-906. https://doi.org/10.1108/jkm-082016-0334.

Pattnaik, S.C., \& Sahoo, R. (2019). Highperformance Work Practices, Affective Commitment of Employees and
Organizational Performance: A Multi-level Modelling Using 2-1-2 Mediation Analysis. Global Business Review, 097215091985910. https://doi.org/10.1177/0972150919859106

Pradesa, H.A., Setiawan, M., Djumahir, \& Rahayu, M. (2013). The Relationships of Perceived Organizational Support (POS) With Positive Work Behavior: Mediating Role of Job Satisfaction, Affective Commitment, and Felt Obligation. IOSR Journal of Business and Management (IOSR-JBM), 13(3), 23-34.

Rhoades, L. \& Eisenberger, R. (2002). Perceived Organizational Support: A Review of the Literature. Journal of Applied Psychology, 87(4), 698-714. https://doi.org/ 10.1037//0021-9010.87.4.698.

Riggle, R. J., Edmondson, D. R., \& Hansen, J. D. 2009. A meta-analysis of the relationship between perceived organizational support and job outcomes: 20 years of research. Journal of Business Research, 62: 10271030.

Rockstuhl, T., Eisenberger, R., Shore, L. M., Kurtessis, J. N., Ford, M. T., Buffardi, L. C., \& Mesdaghinia, S. (2020). Perceived organizational support (POS) across 54 nations: A cross-cultural meta-analysis of POS effects. Journal of International Business Studies, 51(6), 933-962. https://doi.org/10.1057/s41267-020-003113

Sekaran, U., \& Bougie, R. (2016). Research Methods for Business: A Skill Building Approach (7th Edition). Chichester, West Sussex, UK: John Wiley \& Sons.

Shore, L. M., Tetrick, L. E., Lynch, P., \& Barksdale, K. 2006. Social and economic exchange: Construct development and validation. Journal of Applied Social Psychology, 36: 837-867.

Singh, K., Augustine, E. C., \& Desa, Z. M. (2017). Influence of Knowledge Sharing on Job Performance: A Case Study of National Audit Department (NAD). Proceedings of the 2nd Advances in Business Research International Conference, 349-357. https://doi.org/10.1007/978-981-10-60533_33.

Stinglhamber, F., Marique, G., Caesens, G., Desmette, D., Hansez, I., Hanin, D., \& 
Bertrand, F. (2015). Employees'

Organizational Identification and Affective Organizational Commitment: An Integrative Approach. PLOS ONE, 10, e0123955. https://doi.org/10.1371/journal.pone.01239 55

Swift, M. L., \& Virick, M. (2013). Perceived support, knowledge tacitness, and provider knowledge sharing. Group \& Organization Management, 38(6), 717-742. https://doi.org/10.1177/1059601113507597

Teh, P.L. \& Sun, H.Y. (2012). Knowledge Sharing, Job Attitudes and Organisational Citizenship Behavior. Industrial Management \& Data Systems, 112(1), 64-82.

Trivellas, P., Akrivouli, Z., Tsifora, E., \& Tsoutsa, P. (2015). The Impact of Knowledge Sharing Culture on Job Satisfaction in Accounting Firms. The Mediating Effect of General Competencies. Procedia Economics and Finance, 19, 238-247. https://doi.org/10.1016/S22125671(15)00025-8

Usmanova, N., Yang, J., Sumarliah, E., Khan, S. U., \& Khan, S. Z. (2020). Impact of knowledge sharing on job satisfaction and innovative work behavior: the moderating role of motivating language. VINE Journal of Information and Knowledge Management Systems, ahead-of-print(ahead-of-print). https://doi.org/10.1108/VJIKMS-11-20190177

Wang, Q., Weng, Q. (Derek), \& Jiang, Y. (2018). When Does Affective Organizational Commitment Lead to Job Performance? Integration of Resource Perspective. Journal of Career Development, 089484531880758. https://doi.org/10.1177/0894845318807581

Wang, S., \& Noe, R. A. (2010). Knowledge sharing: A review and directions for future research. Human Resource Management Review, 20, 115-131.

Yang, J.-T. (2010). Antecedents and consequences of knowledge sharing in international tourist hotels. International Journal of Hospitality Management, 29(1), 42-52.

https://doi.org/10.1016/j.ijhm.2009.05.004.

\section{CORRESPONDING AUTHOR}

Alex Winarno, email:

winarno@telkomuniversity.ac.id 